\title{
Communications
}

\section{The Impact of Group Speaking Tasks Via SkypeTM on Introvert and Extrovert Learners' Oral Proficiency}

\section{Niloofar Seyed Golshan}

Young Researchers and Elite Club, Science and Research Branch, Islamic Azad University, Language Department, Damavand, Iran

Email address:

golshanniloofar@yahoo.com

\section{To cite this article:}

Niloofar Seyed Golshan. The Impact of Group Speaking Tasks Via SkypeTM on Introvert and Extrovert Learners' Oral Proficiency. Communications. Vol. 3, No. 5, 2015, pp. 102-108. doi: 10.11648/j.com.20150305.14

\begin{abstract}
Exactly as we ask others how many languages they can speak, the ultimate goal that the majority of people wish to accomplish when they attempt learning a foreign/second language is the ability to speak that language fluently, and accurately. This desire for improving in the skill of speaking seems to have turned into a need, as well, in the recent years, owing to the globalization of English language, and its significance in the international communications, education, and trade. Meanwhile, it is fair enough to claim not all learners improve in their speaking at the same pace. Better put, given similar pedagogical quality, learners with different personality variables (e.g. risk-taking, reflectiveness, expressiveness, etc.) are prone to progress in speaking proficiency at different rates. Aiming at using technology as a setting for improving speaking proficiency, this study focused on two basic learner variables - introversion and extroversion - to compare its impacts on introvert and extrovert learners. To draw this comparison, 85 intermediate learners from 4 private English institutes in Tehran were selected on a random basis, and a Cambridge PET test was used to homogenize their general English proficiency, which reduced the population to 64 . A 57-item version of Eysenck Personality Inventory was also used to diagnose the introversion and extroversion of the population, based on which 56 learners - 28 introvert and 28 extroverts - made it to the study. They were exposed to 51 hours of speaking practice via $\mathrm{SKYPE}^{\mathrm{TM}}$ software, participating in a wide variety of pair and group discussions on diverse topics. After administration of the speaking section of the PET test again, as the post-test, and analyzing the results through Independent Samples T-Test, the introvert learners reported a higher rate of progress in their speaking proficiency that the extrovert learners. This proved that introvert learners could gain noticeable benefits in their oral production in the virtual instructional and interactional settings.
\end{abstract}

Keywords: Extrovert Learners, Introvert Learners, Oral Proficiency, Virtual Settings

\section{Introduction}

In the course of the past forty years, the field of SLA has witnessed a major paradigm shift from teacher-centered and language-centered approaches to learner-centered approaches (Kumaravadevelu, 2006). This could be interpreted as the L2 learner is now put on the spotlight, and the whole context of L2 teaching, from approaches to techniques and from text and teacher to equipment, aim at serving the learner and providing him/her with a context that is best geared to his/her own needs, wants, and styles (Crookes \&Chaudron, 1991). In the light of this paradigm shift, SLA research has not just looked into learning theories that attempt to logically argue how do the common public learn L2 the best way and has not just been concerned with devising learning techniques that are applicable to the majority of the learners (Richards
\&Schmidt, 2002), yet it has looked into the personal specifications of the learners, and has endeavored to raise personal attributes of the people on the table, as well.

Dornyei (2005) acknowledged the body of empirical research that targeted individual differences and their impact on L2 learning is significantly sizeable. He, also, added that studying individual differences were mainly concerned with two different parameters: learning styles, and personality variables. In regards with the latter, one of the most popular classifications of personality variables which has been widely applied in the literature of SLA is that of Goldberg (1992, 1993), and McCrae and Costa (2003), which is commonly referred to as the Big Five. The Big Five considered human personality to be stretched across a pendulum of five traits, which are openness to experience, conscientiousness, extraversionversusintroversion, agreeableness, and neuroticism. Of all these traits, the one 
which is tightly tied to the social aspect of the language and has direct potential impact on the quality of L2 learning is the extraversion and introversion (Busch, 1983; Krashen 1981; Skehan, 1989; Strong 1983).

Studies that have looked into the relationships between extroversion/introversion and L2 development have reported results that are in partial contrast with each other. Fillmore (1979) regarded social skills or ability to maintainverbal communications as a factor that enhances language learning. Similarly, Busch (1983) and Rossier (1976) reported that extroversion was an indicator of success. Ellis (1999) justified these remarks by stating extrovertedlearners tend to communicate more easily, and as a result, they receive a larger amount of input. Likewise, Rubin (1975) asserted that having an outgoing personality is essential to generate social settings where one could be exposed to ample input.Wakamoto (2000), as well, reported a positive relationship between functional practice strategies and socialaffective strategies, and the rate of extravation.

On the other hand, Daele (2005), and Oya, Manalo, and Greenwood (2004) did not report any relationships between the extraversion rate and oral performance. Moreover, although Dewaele and Furnham (2000) discovered that extraverted students accomplished greater fluency in an oral production tasks, the discovered there was bare a meaningful relationship between extraversion and writing skill (Dewaele\&Furnham, 1999).In another study, Naiman, Frohlich, Stern, and Todesco (1978) did not report any impact for extroversion in describing the character of a good language learner.

Putting all the above-mentioned and many other reported research results together, it could be concluded that the majority of experts consider extroversion a distinct benefit or rather a bonus in L2 acquisition. Brown (2007) argued that the majority of people in the western culture hold that extrovert people are sharper and more intelligent than the introvert, just because they interact more. He added this is not a wise judgment to make since this is a matter of culture, and what is introvert in the United States might be polite and solemn in another part of the world. Ausubel (1968), also, stated it was unfortunate that stereotypes about extroversion and introversion are causing teachers to pre-judge learners.

In spite of all the research done in the past decades on the role of individual differences in L2 learning, little attention has been paid to devise learning strategies that are geared to learners with different personality variables. Better put, a large amount of time and manpower has been poured into finding correlations between extrication and language learning; yet little effort has been made to find teaching techniques that cater to the needs of introvert and extrovert learners. This seems to be especially necessary in case of oral fluency of introvert learners, since in the modern learnercentered classes of these days, extrovert learners rule the classroom voice. Many teachers take the wrong policy of pushing the introvert learners to out-speak the extrovert ones, but that simply does not work since this pushing toward unwilling unvolunteered self-expression would interfere with their personality and their spontaneous expression in the new language (Littlewood, 1983).

This study aims at utilizing technology to the benefit of introvert learners. These days, the Internet could be found almost in every house in every corner of the world, and Microsoft SKPYE $^{\mathbf{T M}}$, a software program that enables two or more people communicate via text, voice and video, does not seem to be a stranger to the Internet users. The researcher assumed provided speaking activities are done in the virtual atmosphere via SKPYE ${ }^{\text {TM }}$, where learners do not see each other face-to-face, and enjoy the corner den of their own, at least visually, the introvert could find a chance to express themselves more freely and more frequently with the pressure of face-to-face communication off their back. Hence, assumingly, they would gain more interaction with their peers, more exposure to the language both receptively and productively, more L2 input (Ellis, 1999), and as a result flourish and thrive in their L2 speaking skills. To probe this assumption empirically, the following research question was proposed by the researcher:

Are there any differences in the impact of applying group speaking tasks via SKYPE ${ }^{\mathrm{TM}}$ on the oral proficiency of introvert and extrovert learners?

And based on this research question, the following research hypothesis was formulated.

There are not any differences in the impact of applying group speaking tasks via SKYPE ${ }^{\mathbf{T M}}$ on the oral proficiency of introvert and extrovert learners.

\section{Research Methodology}

In order to investigate the research question of this study empirically, an experimental study was designed and implemented, whose details appear to be as follows.

\subsection{Research Design}

This study was of quasi-experimental origin, with two treatment groups (the introvert and the extrovert learners), and the impact of the treatment was measures via a pre-test post-test system. Hence, the design of this study could be illustrated as:

$\begin{array}{lll}\text { R1 } & X & \text { O1 } \\ \text { R2 } & X & O 2\end{array}$

This study had one independent variable, which as orchestrating group speaking tasks via SKYPE ${ }^{\text {TM }}$, and one dependent variable, which was learners' oral proficiency. Learners' extroversion and introversion, as well, were the moderator variables in this study.

\subsection{Participants}

The population of this study, initially, was comprised of 85 supposedly intermediate level English learners in private English institute in North West Tehran, Iran. Administration of a PET test, and homogenizing the participants, both in general English and in speaking skill, reduced this initial population size to 64 . Thanks to the Eysenck Personality 
Inventory, a final 56 participants were selected to enter the study, 28 male and 28 female learners. The participants were all adults (above 18), and they were all either university students or graduates. They were both male and female, and came from various socio-economic backgrounds.

\subsection{Instruments and Material}

Four different instruments were applied by the researcher in the course of the data collection of this study. First, a past paper of the International standard PET test was used as the homogenizing test, to make sure all the learners were of almost equal literacy level of English. This test comes in four papers, and each paper is responsible for one skills (listening, reading, writing, and speaking), and each form $25 \%$ of the whole core. Besides, the speaking section of the PET test was used both as the pre-test and post-test to measure the progress rate of learners' oral proficiency process.

The second instrument applied in this study was the scale of 2012 version of OCR (Oxford Cambridge and RSA Examinations), which was applied to score learners' pre- and post-test speaking performance. This scale measures all aspects of English oral proficiency on a 25 -score basis in three sections: 10 scores for Content and Communication, 10 scores for the Quality of language, and 5 scores for Pronunciation and Intonation.

The third instrument that was utilized in this study was Eysenck Personality Inventory. This psychometric personality test was designed and made by German-born psychologist, Dr. Eysenck, and his colleagues as a means of measuring human personality in two various axes: Introversion/extroversion axis, and Stable-Neurotic axis. There are several different version of Eysenck inventory available, but in this study, the 57-item version of this test was used. This inventory contains three types of scores: lie scores (L), extroversion scores (E), and neuroticism (N), but since this study was mainly concerned with introversion/extroversion, only E scores were paid attention to.

The fourth instrument was the software SKYPE ${ }^{\mathrm{TM}}$, version 5.11.0.102, which was developed by SKYPE and/or MICORSOFT corporations. This software could be installed on all the PCs, tablets, and smart phones, and could provide a multi-media oral communication channel. Via SKYPE ${ }^{\mathrm{TM}}$, learners can join groups, and have listening/speaking practice with their fellow group members. They can also use the voice, on-line chat or even the video chats. Besides, learners have the luxury of recording everything the desire, as well.

However, the only material which was covered throughout the treatment of this study was 6 units of the course book Let's Talk 3 (Jones, 2002), which is a three-level interactive book designed to boost learners' speaking skills. The participants were required to do numerous pair/group work activities on the challenging topics introduced in this study.

\subsection{Procedure}

After homogenizing the participants and determining the introversion/extroversion of their personality, the 52 members of the population were randomly divided into two 28-member groups. It should be noted here that random assignment to the groups happened since both introvert and extrovert learners were supposed to receive the same treatment. Hence, there was no need to separate introvert and extrovert learners from each other, and each experimental group contained a mixture of both personalities. After checking the inter-group homogeneity, the treatment commenced.

The learners of both groups were exposed to 17 three-hour sessions (a total of 51 hours) of treatment via the SKYPE ${ }^{\mathrm{TM}}$ software. At the beginning of each session, the teacher briefed the learners on the topic of the day, and the discussions that were about to take place. Then, the learners were given instructions to the tasks. All the tasks were based on the topics in the first 5 units of Let's Talk 3 (Jones, 2002), and they were all done in a variety of ways, such as in pairs, groups of 2, 3, 4, and 5, rounds, onion-ring, on-off, and the like. After each task, the teacher stopped the groups for several minutes to obtain feedback and answer learners' questions. Based on the needs of the tasks, such as describing each other's appearance, the teacher asked learners to turn on the video chat option, but attempt was made to turn the video option off as far as possible, and use the voice and written chat instead. The researcher assumed that no video communication unless it was absolutely necessary took the pressure of face-to-face communication off the introvert learners' back.

After the treatment was over, all the learners sat in the speaking section of the PET test (the same test as the pre-test) again, this time as the post-test. The same test was repeated because the gap between the two testswas longer than two weeks (Hatch \&Farhady, 1981).

\section{Findings and Data Analysis}

As depicted in Table 1, both Skewness (0.482) and Kurtosis (1.827) were within the range of $\neq 1.95$, and hence the data were distributed normally. The statistical mean of the population's PET scores was 58.27, and the standard deviation was 12.24 . Hence, all the participants with scores within one standard deviation from the mean (within 46.03 and 70.51) were homogeneous in terms of general English. This eliminated 21 participants from the study, and reduced the original 85 members to 64 .

Table 1. Descriptive Statistics of the Homogenizing PET Test.

\begin{tabular}{|c|c|c|c|c|c|c|c|c|c|c|}
\hline & $\mathbf{N}$ & Min & Max & Mean & Std. Deviation & Variance & Skewness & & Kurtosis & \\
\hline & Statistic & Statistic & Statistic & Statistic & Statistic & Statistic & Statistic & Std. Error & Statistic & Std. Error \\
\hline $\begin{array}{l}\text { Homogenizing } \\
\text { Scores }\end{array}$ & PET $_{85}$ & 15 & 95 & 58.27 & 12.246 & 149.962 & .482 & .261 & 1.827 & .517 \\
\hline
\end{tabular}


After the administration of the Eysenck Personality Inventory, 52 learners out of the 64 remaining were considered to have considerably introvert/extrovert personalities. Table 2 illustrates their extroversion/introversion status.

Table 2.The Distribution of Introversion and Extroversion among the Participants via Eysenck Test.

\begin{tabular}{|c|c|c|c|c|c|c|c|c|c|c|c|c|c|c|c|c|c|c|c|c|c|c|c|c|}
\hline \multirow[b]{2}{*}{ Extroversion Percentage } & \multicolumn{10}{|c|}{ Extrovert Personality } & \multicolumn{14}{|c|}{ Introvert Personality } \\
\hline & $0 \quad 0$ & 99 & 99 & 98 & 97 & 95 & 90 & 83 & 74 & 63 & 53 & 43 & 32 & 25 & 18 & 13 & 10 & 6 & 4 & 3 & 2 & 1 & 0 & 0 \\
\hline No. of Items Answered YES & 2423 & 22 & 21 & 20 & 19 & 18 & 17 & 16 & 15 & 14 & 13 & 12 & 11 & 10 & 9 & 8 & 7 & 6 & 5 & 4 & 3 & 2 & 1 & 0 \\
\hline No. of Participants & $0 \quad 0$ & 0 & 0 & 0 & 5 & 6 & 4 & 7 & 6 & 0 & 0 & 6 & 5 & 2 & 11 & 2 & 1 & 0 & 1 & 0 & 0 & 0 & 0 & 0 \\
\hline
\end{tabular}

The speaking scores of the PET test were, also, used as the pre-test scores. As depicted in Table 3, Skewness was -0.004 and Kurtosis was -0.189 , which proved of the normality of data distribution. The average speaking score of the whole population was 14.02 out of 25 , and the standard deviation was 3.371 .

Table 3. Descriptive Statistics of Speaking Pre-Test.

\begin{tabular}{|c|c|c|c|c|c|c|c|c|c|c|}
\hline & $\mathbf{N}$ & Min & Max & Mean & Std. Deviation & Variance & Skewness & & Kurtosis & \\
\hline & Statistic & Statistic & Statistic & Statistic & Statistic & Statistic & Statistic & Std. Error & Statistic & Std. Error \\
\hline $\begin{array}{l}\text { Speaking } \\
\text { Pre-Test }\end{array}$ & 56 & 7 & 22 & 14.02 & 3.371 & 11.363 & -.004 & .319 & -.189 & .628 \\
\hline
\end{tabular}

After determining the pre-test scores, the descriptive statistics of the introvert and extrovert learners' scores were laid out in Table 3. As the table demonstrates, the statistical mean and the standard deviation of the introvert group were 14.04 and 3.061, respectively; and for the extrovert group, they were 14 and 3.712 , respectively. This signified there was a very slight difference between the average scores of the two groups, and introvert and extrovert learners who were chosen for this study had equal scores.

Table 4. Descriptive Statistics of Speaking Pre-Test in Introvert and Extrovert Groups.

\begin{tabular}{|c|c|c|c|c|c|c|c|c|c|c|}
\hline & $\mathbf{N}$ & Min & Max & Mean & Std. Deviation & Variance & Skewnes & & Kurtosis & \\
\hline & Statistic & Statistic & Statistic & Statistic & Statistic & Statistic & Statistic & Std. Error & Statistic & Std. Error \\
\hline $\begin{array}{l}\text { Introvert Group Speaking } \\
\text { Pre-Test }\end{array}$ & 28 & 9 & 21 & 14.04 & 3.061 & 9.369 & .181 & .441 & .249 & .858 \\
\hline $\begin{array}{l}\text { Extrovert Group Speaking } \\
\text { Pre-Test }\end{array}$ & 28 & 7 & 22 & 14.00 & 3.712 & 13.778 & -.103 & .441 & -.413 & .858 \\
\hline
\end{tabular}

Now that the pre-test scores for introvert and extrovert learners were identified, the inter-equality between the pretest scores of the two groups had to be checked via an Independent-Sample T-Test. As Tables 5 and 6 indicate, Levene's Test for Equality of Variances showed the $p$ value of 0.202 , which was larger than 0.05 , and hence it did not report any meaningful differences between the scores of the two groups. Moreover, the $p$ value for the T-Test was 0.969 for the $\mathrm{T}=0.39$ and the mean differences of 0.36 and 0.36 . Since the $p$ value was larger than 0.05 and the mean differences were the same, it could be concluded that introvert and extrovert learners shaped up two equal and homogeneous groups, and they were standard acceptable samples for this study.

Table 5. Group Statistics of Inter-Group Equality Test.

\begin{tabular}{llllll}
\hline & Groups & N & Mean & $\begin{array}{l}\text { Std. } \\
\text { Deviation }\end{array}$ & $\begin{array}{l}\text { Std. Error } \\
\text { Mean }\end{array}$ \\
\hline Speaking & Introverts & 28 & 14.04 & 3.061 & .578 \\
Pre-Test & Extroverts & 28 & 14.00 & 3.712 & .701 \\
\hline
\end{tabular}

Table 6. Inter-Group Equality Independent Samples Test.

\begin{tabular}{|c|c|c|c|c|c|c|c|c|c|c|}
\hline & & \multicolumn{2}{|c|}{$\begin{array}{l}\text { Levene's Test for } \\
\text { Equality of Variances }\end{array}$} & \multicolumn{7}{|c|}{ t-test for Equality of Means } \\
\hline & & \multirow[t]{2}{*}{$\mathbf{F}$} & \multirow[t]{2}{*}{ Sig. } & \multirow[t]{2}{*}{$\mathbf{t}$} & \multirow[t]{2}{*}{ df } & \multirow[t]{2}{*}{ Sig. (2-tailed) } & \multirow{2}{*}{$\begin{array}{l}\text { Mean } \\
\text { Difference }\end{array}$} & \multirow{2}{*}{$\begin{array}{l}\text { Std. Error } \\
\text { Difference }\end{array}$} & \multicolumn{2}{|c|}{$\begin{array}{l}\text { 95\% Confidence Interval of } \\
\text { the Difference }\end{array}$} \\
\hline & & & & & & & & & Lower & Upper \\
\hline \multirow{2}{*}{$\begin{array}{l}\text { Speaki } \\
\text { ng Pre- } \\
\text { Test }\end{array}$} & $\begin{array}{l}\text { Equal variances } \\
\text { assumed }\end{array}$ & 1.669 & .202 & .039 & 54 & .969 & .036 & .909 & -1.787 & 1.859 \\
\hline & $\begin{array}{l}\text { Equal variances } \\
\text { not assumed }\end{array}$ & & & .039 & 52.110 & .969 & .036 & .909 & -1.789 & 1.860 \\
\hline
\end{tabular}

After the administration of the treatment, all the learners sat in the same PET speaking test, and the results were laid out on Table 7. Skewness of -0.12 and Kurtosis of -0.573 signifies that data were normally distributed, and the average mean of 15.45 showed 1.43 scores improvement compared to the initial mean of 14.02. This meant that all the learners had progressed in their oral proficiency as a result of the treatment. 
Table 7. Descriptive Statistics of Speaking Post-Test.

\begin{tabular}{|c|c|c|c|c|c|c|c|c|c|c|}
\hline & $\mathbf{N}$ & Min & Max & Mean & Std. Deviation & Variance & Skewness & & Kurtosis & \\
\hline & Statistic & Statistic & Statistic & Statistic & Statistic & Statistic & Statistic & Std. Error & Statistic & Std. Error \\
\hline $\begin{array}{l}\text { Speaking } \\
\text { Test }\end{array}$ & Post- 56 & 9 & 22 & 15.45 & 3.230 & 10.433 & -.120 & .319 & -.573 & .628 \\
\hline
\end{tabular}

Looking at the average of the two groups in Table 8 , it could be easily observed that the introvert learners, as a whole group, outperformed the extrovert learners in the posttest with the average mean of 16.32 versus 14.57. This provides proof that group speaking tasks through SKYPE ${ }^{\text {TM }}$ had a more productive impact on the introvert learners holistically.

Table 8. Descriptive Statistics of Speaking Post-Test for Introvert and Extrovert Groups.

\begin{tabular}{llllllllll}
\hline & $\mathbf{N}$ & Min & Max & Mean & Std. Deviation & Variance & \multicolumn{2}{l}{ Skewness } & \multicolumn{2}{c}{ Kurtosis } \\
\cline { 2 - 9 } & Statistic & Statistic & Statistic & Statistic & Statistic & Statistic & Statistic & Std. Error Statistic Std. Error \\
\hline $\begin{array}{l}\text { Introvert Group Speaking } \\
\text { Post-Test }\end{array}$ & 11 & 22 & 16.32 & 2.681 & 7.189 & .052 & .441 & -.253 & .858 \\
$\begin{array}{l}\text { Extrovert Group Speaking } \\
\text { Post-Test }\end{array}$ & 9 & 21 & 14.57 & 3.532 & 12.476 & .122 & .441 & -.872 & .858 \\
\hline
\end{tabular}

In order to answer the research question, an Independent T-Test was applied to the speaking scores of the introvert and extrovert learners in the post-test. As the results in Tables 9 and 10 demonstrate, the $p$ value for the $\mathrm{t}=2.088$ was 0.042 , which was smaller than 0.05 , and hence reported a statistically meaningful difference. So the research hypothesis of this study is rejected, and the data analysis signified that applying group speaking tasks via SKYPE $^{\text {TM }}$ did have a different impact on the oral proficiency of introvert and extrovert learners

Table 9. Group Statistics of Post-Test Results.

\begin{tabular}{lcccll}
\hline & Groups & N & Mean & $\begin{array}{l}\text { Std. } \\
\text { Deviation }\end{array}$ & $\begin{array}{l}\text { Std. Error } \\
\text { Mean }\end{array}$ \\
\hline Speaking & Post-Test Introverts & 28 & 16.32 & 2.681 & .507 \\
Scores & Extroverts & 28 & 14.57 & 3.532 & .668 \\
\hline
\end{tabular}

Table 10. Independent Samples Test on Post-Test Results.

\begin{tabular}{|c|c|c|c|c|c|c|c|c|c|c|}
\hline & & \multicolumn{2}{|c|}{$\begin{array}{l}\text { Levene's Test for } \\
\text { Equality of Variances }\end{array}$} & \multicolumn{7}{|c|}{ t-test for Equality of Means } \\
\hline & & \multirow[t]{2}{*}{$\mathbf{F}$} & \multirow[t]{2}{*}{ Sig. } & \multirow[t]{2}{*}{$\mathbf{t}$} & \multirow[t]{2}{*}{ df } & \multirow[t]{2}{*}{ Sig. (2-tailed) } & \multirow{2}{*}{$\begin{array}{l}\text { Mean } \\
\text { Difference }\end{array}$} & \multirow{2}{*}{$\begin{array}{l}\text { Std. Error } \\
\text { Difference }\end{array}$} & \multicolumn{2}{|c|}{$\begin{array}{l}\text { 95\% Confidence Interval } \\
\text { of the Difference }\end{array}$} \\
\hline & & & & & & & & & Lower & Upper \\
\hline Speaking & $\begin{array}{ll}\text { Equal } & \text { variances } \\
\text { assumed } & \end{array}$ & 2.401 & .127 & 2.088 & 54 & .042 & 1.750 & .838 & .070 & 3.430 \\
\hline Post-Test & $\begin{array}{l}\text { Equal variances not } \\
\text { assumed }\end{array}$ & & & 2.088 & 50.360 & .042 & 1.750 & .838 & .067 & 3.433 \\
\hline
\end{tabular}

\section{Discussion and Conclusion}

It was discussed in the prior section that, based on the analysis of the data from this study, the application of group speaking tasks in the virtual world caused further improvement in the speaking skill of introvert learners than extroverts. Although this result might sound bizarre to the ear at the first meet, since extrovert people have always been associated with oral communicational skills, solid arguments could be made and iron-cast reasons could be raised on the table as to why introvert learners outperformed the extroverts in this study, and the key to do so is noticing the nature of the treatment of this study, which took place in a virtual atmosphere.

Although Barrick and Ryan (2003) argued that personality is a dynamicorganization within the individual, and it is a psychophysical system that extends a unique adjustment to its environment, this does not seem to be true of all personality variables. Introvert people find it a big challenge to mingle with people in social settings, and that is a big barrier for them in L2 classes in the view of the fact that they sit silent in the class for most of the class period. Yet, the results of this study reveal that introvert people are well able to socialize in learning environment, hear and be heard, and improve in their fluency in the virtual atmosphere. In other words, Barrick and Ryan's (2003) argument as to the adaptability of personality seems to be operational in case of introverts in L2 learning settings as long as the necessity of face-to-face communication fades away. So unlike face-toface communication settings where introverts are reserved, distant, and quiet (Costa \&Widiger, 2002), in the virtual atmosphere, learners were cheerful, sharing, expressive, and at times talkative. Just as extrovert people, who are willing to communication (McCabe \&Fleeson,2012), introvert people in this study were able to communicate, as well. In fact, the amount of communication they made seems to have been even more educationally productive than the extroverts. 
Another reason that could be offered to explain why introvert learners improved more greatly in oral proficiency compared to the extroverts was that they enjoyed a higher degree of excitation (Eysenck, 1967). Based on Eysenck's theory, introvert people possess a higher amount of excitation, and this excitation gets stronger and larger when the barrier of face-to-face conversation fades away. That is why in the virtual atmosphere, this excitement drove learners toward being more thrilled about expressing themselves, and advancing in their oral proficiency.

One more reason that could be offered for the greater improvement of the introvert learners in the virtual atmosphere is the multi-tasking matter. Liberman and Rosenthal (2001) remarked that extrovert people tend to be good multi-taskers in social situation, and they tend to decode mimics, body language, facial expressions, and the situational moods all at the same time as they are making verbal communication, whereas the introvert could not function so multi-taskingly like this because their mind get too deep in verbal interaction. In this study, the virtual atmosphere took away any type of non-verbal communication except text chat, and as a result, it provided introvert learners with a chance to focus on the speech as much as possible. So they took the best out of this chance to fortify their oral proficiency.

It could, also, be argued that since the learners of this study connected to the Internet at home, and participated in all the speaking tasks at home, they introvert felt safer and less agitated in their own physical territory at home. Thanks to this safety, they felt more at ease to express themselves and share with others. Hence, they received more interaction, more input and more improvements in their oral proficiency.

\section{Pedagogical Implications}

The results of this research, depicting greater progress in oral proficiency of introvert learner over extroverts in virtual atmosphere, could be applicable in various pedagogical contexts. First, English schools could provide their learners with well-equipped language laboratories with high-speed Internet connections, and hold some of the class sessions there rather than always holding it in a regular classroom. This could provide some more chances for the introvert to participate in the oral activities and receive more input.

Besides, teachers or school supervisors could easily pinpoint the introvert learners through psychometric tests, and set some extracurricular activities for them online, so they get a chance to communicate in the virtual atmosphere, and gain better oral practice. This could be even homework for some sessions of the class where the introvert and extrovert sit in the same group, but the introvert would obtain more benefit from it. This is fair since naturally, the extrovert are benefiting more from the regular class in comparison to the reserved learners.

Many researchers have debated over whether or not it is necessary for schools to try to develop social skills of children (Mayer \&Salovey, 1997). In case of doing so, applying group tasks in the virtual atmosphere is definitely a brilliant technique to develop learners' oral skills.

Finally, since people from all throughout the globe could participate in classes held in the virtual atmosphere, learners doing so could gain benefit from having access to native teachers, if possible. In addition, they would be encouraged to expand their domain of friends to an international scale, and get more interaction and oral practice.

\section{Recommendations for Further Research}

The findings of this research and the discussions made on them respond to several questions the answer to which we did not know. Yet, they certainly inspire anyone with scientific curiosity to pursue this research in quest for many other questions it raises. It would be a good idea to do some further research and find out whether speaking tasks in virtual world only strengthen learners' oral proficiency, or does it make their personality more sociable than before as well.

Besides, other personal parameters such as age, gender, career, and education level could be involved in further studies to determine how differently the virtual atmosphere affects male and female introvert and extrovert learners. Also, other personality traits such as risk-takingness, openness to experience, and the like could be studied instead of extraversion, and more fruitful ways for teaching people with those personalities could be devised.

The skill of writing, also, is a good candidate to be swapped with the speaking in this study. Further research could shed some light on the writing instruction aspects of virtual atmosphere.

\section{References}

[1] Barrick, R. M., \& Ryan, A. M. (2003). Personality and Work: Reconsidering the Role of Personality in Organizations. San Francisco: Jossey-Bass.

[2] Brown, D. H. (1993). Principles of language learning and teaching. Englewood Cliffs, NJ: Prentice Hall Regents.

[3] Busch, D. (1982). Introversion-extroversion and the EFL proficiency of Japanese students. Language Learning, 32, 109-32.

[4] Costa, P. T., \&Widiger, A. T. (2002). Personality Disorders and the five- factor model of personality. Washington: American Psychological Association.

[5] Daele, V. S. (2005). The effects of extraversion on L2 oral proficiency. Circulo de LinguisticaAplicada a la Comunicacion, 24, 91-114.

[6] Dewaele, J. M. Furnham, A. (1999). Extroversion: the unloved variable in applied linguistic research. Language Learning, 49(3), 506-544.

[7] Dewaele, J. M. Furnham, A. (2000). Personality and speech production: a pilot study of second language learners. Personality and Individual Differences, 28, 355-365. 
[8] Ellis, R. (1999). Understanding second langauge acquisition. Oxford: Oxford University Press.

[9] Eysenck, H. J. (1967). The biological bases of personality. Sprinfield: Thomas.

[10] Fillmore, L. W. (1979). Individual differences in second language acquisition. In C. Fillmore, D. Kempler, and S. William, (Eds.), Indiviual differences in language ability and language behavior (203-228). Newyork: Academic Press.

[11] Krashen, S. (1981). Second language acquisition and second language learning. Oxford: Pergamon.

[12] McCabe, K. O., \&Fleeson, W. (2012). What is Extraversion For? Integrating Trait and Motivational Perspectives and Identifying the Purpose of Extraversion. Psychological Science, 23, 1498-1505.

[13] Naiman, N., Frohlich, M., Stern, H. H., \&Todesco, A. (1978). The good language learner: Research in education. Toronto, Ontario, Canada: Institute for Studies in Education.
[14] Rossier, R. (1976). Extroversion-introversion as a significant variable in the learning of oral English as a second language. Unpublished $\mathrm{Ph}$. D. dissertation, University of Southern California.

[15] Rubin, J. (1975) What the good language learner can teach us? TESOL Quarterly, 9, 41-51.

[16] Skehan, P. (1989). Individual differences in second-language learning. Londan: Erdward Arnold.

[17] Strong, M (1983). Social Styles and the second language acquisition of Spanish speaking kindergartnes. TESOL Quarterly, 17:241-58.

[18] Wakamoto, N. (2000). Language learning strategy and personality variables: Focusing on extroversion and introversion. International Review of Applied Linguistics, 38 (1), 71-81. 